\title{
sciendo EFFECT OF HUMAN FACTOR ON PRODUCT QUALITY IN MANUFACTURING ACTIVITIES
}

doi:10.2478/mape-2018-0107

Date of submission of the article to the Editor: 05/2018

Date of acceptance of the article by the Editor: 07/2018
MAPE 2018, volume 1, issue 1, pp. 851-856

\author{
Mgr inż. Sara Gruszka \\ Silesian University of Technology, Poland \\ doc. Ing. Štefan Gašpar, PhD \\ Technical University Kosice, Slovak Republic
}

\begin{abstract}
Human factor, often referred to in the literature as human resources, is an important type of resources in an enterprise in ensuring the highest possible quality of products and meeting the needs of customers. The paper presents the question of influence of human factor on the quality of manufacture of the finished product in individual stages of the production process. This problem was presented based on literature analysis and on observations in a production business. Due to the ever-increasing significance of human influence on product quality, this issue is not only very timely, but is constantly being developed.
\end{abstract}

Keywords:quality, product quality, human resources, production process, finished product.

\section{INTRODUCTION}

Nowadays, a thriving economy means that users, and above all, the creators of both Polish and foreign markets are forced to pay particular attention to the increasingly diverse interdependencies between the society and the trend of progressive technologies. This process may be observed especially in production companies, when introducing new products to the company's offer, and by this employing new production methods and processes. It is becoming clearer that the objective of implementing changes in manufacturing technologies and production processes is development of an enterprise, desire to become a leader in the product's main market, and subsequently register a significant increase in the profits of an organization (Gembalska-Kwiecień, 2017).

However, very often, reluctance of employees to introduce changes, often resulting from the lack of appropriate competence and experience, constitutes a major stumbling block. According to the literature, this phenomenon is identified with a social zone and not, as it had been pointed out so far, with the technical sphere. It should be noted that employees' aversion to change is motivated by the fear and probability of risk of failure when getting involved in new methods, which are often temporary and with time become trivial and go to pass on by themselves. Therefore, for this reasons, the change sintroduced both in the production process and in the technology itself must be characterized by an appropriate organization as well as management of implemented changes. Every innovation should be of a staged nature and introduced gradually, thus giving employees the chance to learn about it and understand the nature of its implementation (Midor, 2014).

The fact is that under market economy conditions and rapidly developing competition providing consumers with the best possible quality of products and services, which is a prerequisite for survival in today's market, is very important. That is why, in order to meet the expectations of as many customers as possible, it is necessary to constantly search for the newest production 
and technological as well as financial solutions. The way to understand the quality that is desired by contractors in the market is to know their needs and target expectations. This is one of the important factors significantly affecting the effectiveness of an enterprise's conducted economy. The very rapid social, economic, and technological development constitute a very characteristic feature of today's times. Each organization is geared towards continuous improvement. The main purpose of undertaking these activities is to strengthen or improve position on the sales market and increase the level of profit achieved by an enterprise. There are many methods, tools, and techniques in the literature, with whose help it is possible to increase the efficiency of the production process, leading to improvement of the quality of the products themselves. It had always been stated until now that the said production zone is often neglected and underestimated, for, after all, it is potentially the main source of gaining a competitive advantage by a company. The way to achieve this is through offering customers products meeting their expectations and satisfying their specific needs (Molenda, 2014).

The article aims to present the significant influence that the human factor has on the quality of products in enterprises based on observations carried out on a company trading in steel components and on literature review. The article presents technical definitions of quality in two perspectives: importance of the human factor from engineering point of view and the juxtaposed impact of human capital on a specific stage in the manufacture of finished product in manufacturing enterprises.

\section{METHODOLOGY OF RESEARCH}

Quality is the overall property and characteristics of a product related to its ability to meet consumer needs and expectations. The quality of the final product is significantly dependent on several factors that are difficult to rank. These include the quality of machine and equipment materials as well as quality of technical service.

Product quality is also a function of many variables and the sum of various factors of a technical, economic, psychological, and organizational nature. In a market economy, quality depends to a large extent on the ever-increasing quality requirements of users and final consumers (Prozorowicz, 2001).

The technical factors previously pointed out constitute the basis for the quality of products, as developments in science and technology constantly create new opportunities in terms of quality. Factors of a technical nature determine the quality of products throughout their life cycle, thus both in the pre-production and post-production phases. Economic factors are visible mainly in the involvement of capital and choice related to the most appropriate use of the opportunities created by the technology in the present times. Factors of psychological nature are particularly visible in the form of reactions to prevailing working conditions, but also to interpersonal relationships in the workplace. They strongly affect each other and, in addition, they are closely related to both technical and economic factors that determine the quality of production. The fourth important subgroup is the organizational factors that come to the fore mainly when solving organizational problems related to managing quality control (Krzemień and Wolniak, 2007).

The literature is abound with countless technical definitions of quality strictly related to the qualitative characteristics of products. A number of these have been presented in table 1 below.

There are very many product quality features can be distinguished and they can be grouped in different ways. The most common division is the one into technical, utilitarian, aesthetic, and economic features as well as ergonomic, ecological, and logistic. 
Table 1

Selected definitions of technical quality.

\begin{tabular}{|l|l|}
\hline \multicolumn{1}{|c|}{ Author } & \multicolumn{1}{c|}{ Definition } \\
\hline B. Miszewski & Quality is a set of physical features that help meet specific human needs. \\
\hline R. Chwieduk & $\begin{array}{l}\text { The technical quality of a product is determined by the physicochemical properties and } \\
\text { is a function of the product's material characteristics. }\end{array}$ \\
\hline W. Krencik & $\begin{array}{l}\text { Quality is a set of features of every product concerning the level of technological } \\
\text { innovativeness, reliability, usable performance, efficiency, shape, color, etc. All the } \\
\text { product features mentioned above can be considered from the point of view of } \\
\text { construction or technology of used raw materials, materials, or finishing methods. }\end{array}$ \\
\hline B.A. Dubowikow & $\begin{array}{l}\text { The quality of an industrial product is generally understood as the overall properties } \\
\text { determining its suitability for intended use. }\end{array}$ \\
\hline S. Dulski & $\begin{array}{l}\text { The only rational concept of quality is the technical quality of a product and production } \\
\text { derived from the factual characteristics of the products. }\end{array}$ \\
\hline
\end{tabular}

Source: (Horbaczewski, 2006).

The main features determining the quality of a product include:

- technical features - defining the technical parameters of a product structure and technology that in a significant way affect the quality of the product,

- aesthetic features - characterizing the external appearance and finish of the final products, taking into account the requirements and expectations of the customer. The qualities experienced by the senses, i.e. sound, smell, and taste, also belong to the described group,

- economic features - include acquisition, installation, depreciation, and operating costs, cost of maintenance, storagee, and repairs,

- functional features - determine the safety of use, functionality, and product reliability,

- ergonomic features - describe the degree of adaptation of the final product to the anatomical, physiological, and psychological features of its users,

- ecological features - characterize interaction between the product and the natural environment, taking into consideration the use of non-renewable raw materials and energy,

- logistics characteristics - determine the optimal conditions for the flows of all raw materials, materials, and related information (Sęp and Pacyna 2011).

The quality level of products is regulated by competitiveness, which constitutes a very important factor determining the quality of finished products under a balanced market situation. Therefore, it is essential to adapt the quality of manufactured products to the expectations and requirements of consumers as well as to produce more and more innovative products that can compete with the leading producers on the market. For the reason, therefore, it is very important to put emphasis on both the quality factors discussed above and the quality characteristics of finished products that affect the entire product cycle, starting from the preproduction phase to the post-production phase (Wolniak et al., 2016).

At present, human capital in businesses constitutes the basis for creating new, unique solutions for satisfying the needs and expectations of customers. It is precisely the people in the company who are the initiators and implementers of innovative solutions and ideas that guarantee survival on such a large competition market. Without human resources, other resources, such as financial or material resources, become useless, because it is a human being who has the individual ability to make decisions on creating undertakings that become successful or non-successful. That is why it is very important to invest and take care of both the professional and intellectual development of employees, because this is a strategic investment that will be quickly reflected in the company's profits. Human factor as a resource is the only resource that definitely increases in value with the passage of time and use, at the same time it is inexhaustible and does not age as opposed to technologies or production machines (Gembalska-Kwiecień, 2017).

In the enterprise, the human factor is treated as a complement of the organizational structure during production of products as well as evaluation of the quality of the final products. It 
consists of groups of people and units jointly carrying out assigned tasks and duties. Through the identification of human factor that is a significant to an organization, one can notice the importance of human being in efficient and effective implementation of the company's strategic and qualitative goals. This is important when striving to carryout works that fully comply with product quality requirements. This phenomenon applies not only to employees directly related to production, but also to those who have indirect contact with it. As it is obvious that each employee has a significant impact on the quality of manufactured products in the enterprise (Frąś and Siwkowski, 2011).

\section{RESULTS AND DISCUSSION}

The human factor is a very important procedural criterion in the process of creating a given product. Its significance manifests itself at every stage of product creation, starting from identification of production needs of a given product, through designing, its production, quality control, right to the sales to the consumer. Table 2 presents the stages of emergence of final products along with the action, where the human has the key impact on the quality of the product (Nowak and Pacholski, 2009).

Table 2

Influence of the human factor on the quality of the stages of finished product manufacture.

\begin{tabular}{|c|c|c|}
\hline No. & Stage of product manufacture & In reference to the human factor \\
\hline 1. & Diagnosis of consumer needs. & $\begin{array}{l}\text { The customer is treated as the most important element of the } \\
\text { company's existence on the competitive market. It is them and their } \\
\text { expectations and needs that are the most important for producers. } \\
\text { Therefore, at any moment, it is crucial to detect the possibilities of } \\
\text { satisfying the emerging needs in the lives of potential clients. }\end{array}$ \\
\hline 2. & $\begin{array}{l}\text { Analysis of the possibility of } \\
\text { introducing a product to the } \\
\text { market. }\end{array}$ & $\begin{array}{l}\text { This stage often constitute a key stage during the manufacture of a } \\
\text { new product, because at this moment the product vision is confronted } \\
\text { with its implementation, production capabilities, and opportunity to } \\
\text { market a new product. The decision to start the project is taken by } \\
\text { the human being. }\end{array}$ \\
\hline 3. & Designing of product. & $\begin{array}{l}\text { Cooperative work, and often team work, of many people during the } \\
\text { creation of a new product design aims to achieve the initially set goals } \\
\text { of designing product quality meeting the requirements of potential } \\
\text { users, taking into account the economic considerations of production } \\
\text { and future safety when using a new product. }\end{array}$ \\
\hline 4. & $\begin{array}{l}\text { Production process of the } \\
\text { finished product. }\end{array}$ & $\begin{array}{l}\text { A prerequisite for success in the implementation of a given stage is } \\
\text { the selection of people, machines, and materials with capabilities; in } \\
\text { the case of people, knowledge and competences to participate in the } \\
\text { production process. The employer's task is to provide the necessary } \\
\text { equipment, access to information, as well as to create optimal } \\
\text { conditions for employees who during each process operation decide } \\
\text { on its quality. }\end{array}$ \\
\hline 5. & $\begin{array}{l}\text { Quality control of the final } \\
\text { product. }\end{array}$ & $\begin{array}{l}\text { Carrying out measurements and tests of the resulting productas well } \\
\text { as checking the color, shape, taste, or smell is the key, most } \\
\text { important moment of the whole process of manufacturing a new } \\
\text { product. It is this stage that decides whether a given party, piecewill } \\
\text { reach theend user, the requirements of whom it has to meet and who } \\
\text { is the potential contractor of the company on the market. Therefore, } \\
\text { the human capital of any organizational unit constitutes the most } \\
\text { important element of the company's structure, whose continuous } \\
\text { improvement and development is aprerequisite for effective } \\
\text { productivity. }\end{array}$ \\
\hline
\end{tabular}

Source: Own study based on observations in the enterprise.

Through analyzing individual stages of product development, it can be seen that the human is a key factor in the entire production process, and the stereotypes of complete replacement of human work and resources by the work of machines and devices constitute a serious 
challenge in these times. Table two presents tages of product creation with the influence of the human factor that is visible during the implementation of each stage. It is without question that investment in human capital by an enterprise is a profitable and strategic investment, which will constitute the main source of profits for the organization. Treating employees as easily replaceable elements is very popular in the operation of manufacturing enterprises; however, it is ill-advised and leads to failure to achieve an organization's intended goals. Very important to any enterprise is the qualitative consideration of any changes in the human capital of an enterprise as well as the requirement to use innovative concepts of human factor management in the enterprise. This process leads to an effective organization system and thus to production and manufacture process of products in accordance with the requirements of users.

\section{CONSLUSION}

Continuous and systematic improvement of its resources constitute a prerequisite for ensuring that a company will function efficiently. Only human resources, neither material nor technological resources, are crucial from the point of view of the strategic action of any organizational unit. Human resources, otherwise referred to in literature as human factor, are decisive in the field of emerging opportunities to meet expectations imposed on the market by the consumers. They are the most important element for efficient and effective functioning of the entire organization. However, it should be noted that besides being oriented towards the human being, production processes should also be oriented towards creating an unrivaled product on the Polish and foreign market (Gawlik and Kietbus, 2008).

In the process of building a long-term strategy of a growing enterprise, it is important to consider the human factor, which constitutes a crucial element in the planning and introduction of any changes to an organization; because this real person is the originator and creator, and now the implementer, and also takes care of the quality of the changes, and at the final stage is forced to adapt and accept new developments. Man is responsible and has a huge impact on the quality of each stage of manufacturing a product or service -they are the decisionmakers and bearall the consequences of any actions taken.

It should be noted that the most important requirement under the current market conditions is to ensure the expected quality of manufactured products. In order for this goal to be accomplished, one should invest through a series of specialist courses and trainings in the human capital of an enterprise, for this represent the future of an organization. It is recommended to invest financial resources in modern technologies that allow for streamlining of processes, modernization of production lines, and implementation of innovative quality control methods that facilitate elimination of production errors (Nowicki and Sikora, 2010).

The constant development and volatility of the market economy demands from producers searching for newer and more innovative methods and tools in order to meet the expectations of potential customers. The conducted analysis shows that the human being is a decisionmaking body, hence it becomes obvious that employees form an irreplaceable element in the process of product creation. No operations can take place without human input, for this reason it is without doubt that in any enterprise human capital constitutes the most important determinant of the efficiency of the production process, and thus the quality of the manufactured products.

\section{ACKNOWLEDGEMENTS}

The paper is the result of statutory research carried out at the Institute of Production Engineering at the Faculty of Organization and Management of the Silesian University of Technology as part of a project number 13/030/BK_18/0039 called "Development of intelligent production methods as well as work and life environments in the context of production engineering challenges". 


\section{REFERENCES}

Frąś, J. and Siwkowski, M. (2011). Metody I techniki zarządzania jakością. Szczecin: Zeszyty naukowe Uniwersytetu Szczecińskiego, 685.

Gawlik, J. and Kiełbus, A. (2008). Metody I narzędzia w analizie jakości wyrobów.

Gembalska-Kwiecień, A. (2017). Improving safety culture in the enterprise based on attitudes and behavior of its employees.

Gembalska-Kwiecień, A. (2017). Development of an Innovative Methodology Supporting Project Risk Management in the Manufacturing Company of the Automotive Industry, ICORES, pp. 265-271.

Horbaczewski, D. (2006). Filozoficzne źródła współczesnego pojmowania jakości. Problemy Jakości, 10 , pp. $10-15$.

Krzemień, E. and Wolniak R. (2007). Problems of incentives for employees in the quality management of the service sector. Quality and Quantity, 5, pp. 749-756.

Midor, K. (2014). Innovations in the field of enterprise quality management as an element of sustainable development implementation, STEF92 Technology, pp. 215-222.

Molenda, M. (2014). Uwarunkowania jakości badania satysfakcji klientów. Systemy Wspomagania w Inżynierii Produkcji, Jakośći Bezpieczeństwo, Gliwice: PA NOVA, pp. 154-163.

Nowak, W. and Pacholski, L. (2009). Human factors in improving process of company organizational culture. Poznań: Publishing House of Poznań University of Technology, pp. 61-74.

Nowicki, P. and Sikora, T. (2010). Czynniki kształtujące satysfakcję klienta oraz korzyści z pomiaru satysfakcji klienta w procesie doskonalenia jakości. Wydawnictwo Naukowe PTTŻ.

Prozorowicz, M. (2001). Ekonomiczne determinant kształtowania jakości wyrobu w przedsiębiorstwie. Szczeciń: Wydawnictwo Naukowe Uniwersytetu Szczecińskiego, pp. 25-32.

Sęp, J. and Pacyna A. (2011). Metody I narzędzia zarządzania jakością. Rzeszów: Oficyna Wydawnicza Politechniki Rzeszowskiej.

Wolniak, R. et al (2016). Evaluation of the level of quality with regard to architectural barriers according to the degree of disability. 3th International Multidyscyplinary Scientific Conference on Social Sciences and Art. SGEM 2016, pp. 6-9. 